\title{
Plant species diversity impacts nitrogen removal and nitrous oxide emissions as much as carbon addition in constructed wetland microcosms
}

\author{
Wenjuan Han ${ }^{\mathrm{a}}$, Jie Chang ${ }^{\mathrm{a}}$, Xing Fan ${ }^{\mathrm{a}}$, Yuauyuan Du ${ }^{\mathrm{a}}$, Scott X Chang ${ }^{\mathrm{b}}$, \\ Chongbang Zhang ${ }^{\mathrm{c}}$, Ying Ge $\mathrm{a}^{\mathrm{*}}$ \\ a College of Life Sciences, Zhejiang University, 866 Yuhangtang Road, Hangzhou \\ 310058, P. R. China \\ ${ }^{\mathrm{b}}$ Department of Renewable Resourse, University of Alberta, Edmonton T6G 2E3, \\ Alberta, Canada \\ ${ }^{\mathrm{c}}$ College of Life Sciences, Taizhou University, Jiaojiang 318000, PR China
}

${ }^{*}$ Corresponding author. Tel./ fax: +86 57188206465.

E-mail address: geying@ zju.edu.cn (Y. Ge) 


\begin{abstract}
With the aim to develop an approach for treating wastewater with low carbon (C) to nitrogen $(\mathrm{N})$ ratio in constructed wetlands $(\mathrm{CWs})$, we compared the effects of $\mathrm{C}$ addition and species diversity on $\mathrm{N}$ removal and nitrous oxide $\left(\mathrm{N}_{2} \mathrm{O}\right)$ emissions. Compared with the monocultures without $\mathrm{C}$ addition, $\mathrm{C}$ addition significantly increased $\mathrm{N}$ removal efficiency in monocultures (reached $71 \%$ on average); increasing species richness impacted $\mathrm{N}$ removal as much as $\mathrm{C}$ addition, and the $\mathrm{N}$ removal efficiency in the four-species mixture reached $75 \%$. Both $\mathrm{C}$ addition and species richness level significantly increased $\mathrm{N}_{2} \mathrm{O}$ emission rates (reached 1.26 and $1.40 \mathrm{mg} \mathrm{m}^{-2} \mathrm{~d}^{-1}$, respectively), but had no significant effect on $\mathrm{N}_{2} \mathrm{O}$ emissions per unit $\mathrm{N}$ removal. The effects of species richness on $\mathrm{N}$ removal and $\mathrm{N}_{2} \mathrm{O}$ emissions were stronger than species identity. Compared with $\mathrm{C}$ addition, assembling plant communities with high diversity in actual applications could be an effective and more economical approach for treating wastewater with low $\mathrm{C} / \mathrm{N}$ ratio in $\mathrm{CWs}$.
\end{abstract}

Keywords: Species richness; Species identity; Ecosystem function; Carbon source. 


\section{Introduction}

With the rapid growth of population and urbanization, the increasing production of wastewater with high-strength nitrogen $(\mathrm{N})$ has become a serious problem impacting water quality, air quality and human health (Galloway et al., 2008; Schwarzenbach et al., 2010). A large amount of nitrous oxide $\left(\mathrm{N}_{2} \mathrm{O}\right)$ is emitted during wastewater processing (Kampschreur et al., 2009; Huang et al., 2013). Thus, it is of great significance to develop technologies to treat wastewater that has high $\mathrm{N}$ removal and low $\mathrm{N}_{2} \mathrm{O}$ emissions.

Constructed wetlands (CWs) have been widely used for treating various wastewaters with the benefit of low operation and maintenance requirements (Vymazal et al., 2007; Liu et al., 2012). Yet, there are great differences in the ratio of $\mathrm{C}$ to $\mathrm{N}(\mathrm{C} / \mathrm{N})$ among different sources of wastewater (Wu et al., 2014, Vymazal, 2014). Wastewater from some high-tech industry sources, such as semiconductors and optoelectronics, has a very low $\mathrm{C} / \mathrm{N}$ ratio (Kumar et al., 2012). The influent $\mathrm{C} / \mathrm{N}$ ratio, representing the relative amount of $\mathrm{C}$ source available in a system, plays a crucial role in $\mathrm{N}$ removal and $\mathrm{N}_{2} \mathrm{O}$ emissions in CWs (Huang et al., 2013). Lack of available organic carbon could inhibit biological $\mathrm{N}$ removal in CWs, cause incomplete denitrification and increase $\mathrm{N}_{2} \mathrm{O}$ emissions in CWs at the same time (Kampschreur et al., 2009; Huang et al., 2013). Finding ways to improve the performance of $\mathrm{CWs}$ for treating wastewater with a low $\mathrm{C} / \mathrm{N}$ ratio has been an active area of research.

Adding labile $\mathrm{C}$ to wastewater to enhance the denitrification is an approach that can be used to improve the $\mathrm{N}$ removal in $\mathrm{CWs}$ for treating wastewater with a low $\mathrm{C} / \mathrm{N}$ ratio (Sirivedhin and Gray, 2006; Wu et al., 2014). However, excessive C availability in 
wastewater often competes for limited oxygen supply and then inhibits nitrification (Saeed and Sun, 2011). In addition, as $\mathrm{C}$ addition obviously increases the cost (Wu et al., 2014), finding the low-cost alternative approaches are needed.

Plants in CWs can provide organic matter as the $\mathrm{C}$ sources for denitrification (Picek et al., 2007). The soil C pool in different systems varies with the plant productivity, chemical composition of root exudates, turnover rate of the root, and composition and activity of microbial community in the rooting zones. (De Deyn et al., 2008). Increasing species richness not only increases the soil C pool (Chang et al. 2014; Lange et al., 2015), but also increases plant productivity and plant $\mathrm{N}$ uptake, and then increases the $\mathrm{N}$ removal (Ge et al., 2015). In addition, assembling plant communities with several species almost does not raise the cost than monoculture, so increasing plant diversity should be an economical approach for substituting $\mathrm{C}$ addition to improving $\mathrm{N}$ removal in CWs.

Nitrous oxide is a byproduct of nitrification and an intermediate product of denitrification (Canfield et al., 2010). Regulating the $\mathrm{C} / \mathrm{N}$ ratio by $\mathrm{C}$ addition may be an approach that can be employed to control $\mathrm{N}_{2} \mathrm{O}$ emissions. Wu et al. (2009) reported that when influent $\mathrm{C} / \mathrm{N}$ ratio is $5, \mathrm{~N}_{2} \mathrm{O}$ emission from $\mathrm{CWs}$ was the minimum. Plant species richness may also affect $\mathrm{N}_{2} \mathrm{O}$ emissions by influencing biotic and abiotic factors, such as microbial communities, $\mathrm{N}$ concentrations, and availability of $\mathrm{C}$ sources (Thomson et al., 2012). In grassland ecosystem, $\mathrm{N}_{2} \mathrm{O}$ emissions decreased with species richness (Niklaus et al., 2006) or no response (Abalos et al., 2014) or. In CWs for treating wastewater without extra $\mathrm{C}$ input, $\mathrm{N}_{2} \mathrm{O}$ emissions increase with increasing species richness (Sun et al. 2013; Chang et al., 2014). In order to determine whether assembling 
high species richness could replace $\mathrm{C}$ addition when treating wastewater with low $\mathrm{C} / \mathrm{N}$ ratio in CWs, it is important to compare the effects of these two approaches on $\mathrm{N}_{2} \mathrm{O}$ emissions.

Species identity (species composition) is an important component of species diversity. In fact, species identity can play a greater role in controlling ecosystem productivity than species richness in grassland and marine communities (Hooper and Vitousek, 1998; Bruno et al., 2005). Abalos et al. (2014) demonstrated that species identity surpasses species richness as a key driver of $\mathrm{N}_{2} \mathrm{O}$ emissions in a grassland ecosystem. In CWs, species identity can significantly affect ecosystem productivity (Sun et al., 2013; Ge et al., 2015), N removal (Read et al., 2008; Ge et al., 2015) and $\mathrm{N}_{2} \mathrm{O}$ emissions (Sun et al., 2013). As such, it is key to further understand the relative importance of species identity and species richness on $\mathrm{N}$ removal and $\mathrm{N}_{2} \mathrm{O}$ emissions in CWs.

In this study, microcosms simulating vertical flow CWs were established. These microcosms included monoculture and mixture of plant species. All plant communities were supplied with a simulated wastewater with or without $\mathrm{C}$ (sucrose) addition. The objectives of this study were to (1) investigate the effects of $\mathrm{C}$ addition on $\mathrm{N}$ removal and $\mathrm{N}_{2} \mathrm{O}$ emissions; (2) study the effects of species richness and identity on $\mathrm{N}$ removal and $\mathrm{N}_{2} \mathrm{O}$ emissions; (3) compare the effects of plant diversity and $\mathrm{C}$ addition on $\mathrm{N}$ removal and $\mathrm{N}_{2} \mathrm{O}$ emissions.

\section{Materials and methods}

\subsection{Experimental design}


The study was conducted in 50 simulated vertical flow CWs microcosms in an open field at Zhejiang University $\left(30^{\circ} 18^{\prime} \mathrm{N}, 120^{\circ} 05^{\prime} \mathrm{E}\right.$, Hangzhou City, Southeast China). The microcosms were constructed using ceramic tubs $(53 \mathrm{~cm}$ long $\times 17.5 \mathrm{~cm}$ wide $\times 18.5 \mathrm{~cm}$ high) and filled with coarse sand $(0.5-3 \mathrm{~mm})$ to a depth of about $12 \mathrm{~cm}$.

On the basis of the physiological and morphological traits, which influence the resource requirements and growth traits, four common local plant species, Juncus effusus L., Oenanthe javanica (Blume) DC, Phalaris arundinacea L. and Rumex japonicus Houtt. were selected for the experiment. The seedlings were transplanted into microcosms with a density of 12 individuals per microcosm in March 2013.

In this study, the simulated wastewater was based on the Hoagland nutrient solution (Hoagland and Arnon, 1950) with minor modifications. Nitrate-N was the sole $\mathrm{N}$ source, and the concentration $\left(336 \mathrm{mg} \mathrm{L}^{-1}\right)$ was three times higher than that of Hoagland. Four treatments were used here: (1) monocultures supplied with simulated wastewater without $\mathrm{C}$ addition was set as the control; (2) monocultures supplied with simulated wastewater with C addition; (3) high species richness (four-species mixture) supplied with simulated wastewater without $\mathrm{C}$ addition; and (4) four-species mixture supplied with simulated wastewater with $\mathrm{C}$ addition. As shown in Fig. 1, the experiment was arranged in a completely random block design with five replicates laid out in five blocks, totally 50 microcosms.

For the experiment supplied with simulated wastewater with $\mathrm{C}$ addition, sucrose was added to create chemical oxygen demand (COD) to $\mathrm{N}$ ratio (1:1). The simulated wastewater was supplied once every ten days, for a total of eight times. During the experiment, each microcosm received $18.816 \mathrm{~g}$ total inorganic $\mathrm{N}$ (TIN). The water level 
was kept at $1.5 \mathrm{~cm}$ above the sand surface of each microcosm, and each microcosm contained $7 \mathrm{~L}$ of simulated wastewater. The microcosms were supplied daily with tap water to compensate for evaporation loss.

\subsection{Sampling and measurements}

Water samples were taken on the eighth day after the last supply of simulated wastewater and then were stored in a freezer at $-20{ }^{\circ} \mathrm{C}$. Each water sample was filtered using a membrane syringe filter (pore size $0.45 \mu \mathrm{m}$ ) before analysis. The total organic $\mathrm{C}$ concentration (TOC) in water was measured by the non-dispersion infrared method, the nitrate- $\mathrm{N}$ and ammonium- $\mathrm{N}$ concentrations were measured by spectrophotometric method (Clescerl et al., 1999), although nitrate-N was the sole $\mathrm{N}$ source, the ammonium-N may come from the organic $\mathrm{N}$ released by plants (Chang et al., 2014). The sum of nitrate- $\mathrm{N}$ and ammonium- $\mathrm{N}$ concentrations is the TIN concentration. The $\mathrm{N}$ removal efficiency (NRE) in the last batch of supplying simulated wastewater was calculated based on mass balance:

$\operatorname{NRE}(\%)=\left(N_{i}-N_{e}\right) / N_{e} \times 100$

where $N_{i}$ is the amount of influent TIN of each microcosm (mg); $N_{e}$ is the amount of effluent TIN of each microcosm (mg).

Gas samples were collected on the eighth day after the last supply of simulated wastewater using the static chamber method described in Chang et al. (2014). The PVC static chambers $(24 \mathrm{~L})$ were placed on the ground surface of microcosms. The gas collection was carried out from 8:00 to 10:00 am at 30 min intervals. Gas samples were collected in $100 \mathrm{~mL}$ gas sampling bags (Plastic gas, Delin Company, China) using 50 $\mathrm{mL}$ polyurethane syringes. The air temperature inside the chamber was monitored 
during gas collection. The $\mathrm{N}_{2} \mathrm{O}$ concentration was determined using a gas chromatograph (Agilent - 7820, USA). The $\mathrm{N}_{2} \mathrm{O}$ emission rate $\left(\mathrm{mg} \mathrm{m} \mathrm{m}^{-2} \mathrm{~d}^{-1}\right)$ was calculated according to the equation described in Cheng et al. (2007). Then $\mathrm{N}_{2} \mathrm{O}-\mathrm{N}$ emission per unit $\mathrm{N}$ removal $\left(\mathrm{mg} \mathrm{g}^{-1}\right)$ was calculated as the $\mathrm{N}_{2} \mathrm{O}-\mathrm{N}$ emission per day divided by TIN removal per day in the last batch of supplying simulated wastewater.

At the end of the experiment, all plants were harvested by species, cleaned and measured for above- and below-ground biomass after the samples were oven dried at $65{ }^{\circ} \mathrm{C}$ for $72 \mathrm{hr}$. Dry plant tissue materials were ground to the fine powders. Then plant tissue $\mathrm{N}$ concentrations and foliar $\delta^{15} \mathrm{~N}$ value were measured using an isotope ratio mass spectrometer linked to an elemental analyzer (Flash HT2000, Thermo Finnigan, Bremen, Germany). Plant tissue $\mathrm{N}$ pools were calculated by multiplying tissue $\mathrm{N}$ concentration per species by its tissue biomass. Above- and below-ground $\mathrm{N}$ pools were summed to obtain the total $\mathrm{N}$ pool. The contribution of plant $\mathrm{N}$ uptake to TIN removal was calculated as total $\mathrm{N}$ pool divided by TIN removal across the experiment based on the mass balance.

\subsection{Statistical analysis}

In order to compare the effects of $\mathrm{C}$ addition and increasing species richness on $\mathrm{N}$ removal and $\mathrm{N}_{2} \mathrm{O}$ emissions, one-way ANOVA was used to test for treatment effects and Least Significant Difference (LSD) contrasts to correct for multiple comparisons (Tilman et al., 2012). Student's t-test was used to detect significant differences in $\mathrm{N}$ removal, $\mathrm{N}_{2} \mathrm{O}$ emissions, biomass, $\mathrm{N}$ pool and foliar $\delta^{15} \mathrm{~N}$ of four monocultures between the treatments with and without $\mathrm{C}$ addition. If necessary, the data were log-transformed to meet the statistical assumptions of the tests. To investigate the effects of species 
richness and identity on $\mathrm{N}$ removal, $\mathrm{N}_{2} \mathrm{O}$ emissions, biomass and $\mathrm{N}$ pool, one-way ANOVA was performed for each experiment, including all monocultures and the most diverse mixture (four-species mixture). The treatment sum of squares was partitioned into a priori contrast (richness effect) between the highest diverse mixture and the monocultures (Bruno et al., 2005). The residual sum of squares reflected the variation among the monocultures, thus representing the identity effect. Both effects were tested using the error mean square as the denominator in the F-test. We calculated the magnitude of effect $\left(\omega^{2}\right.$, the relative contribution expressed as the percentage of the total variance) for the species richness and identity effects (Graham and Edwards, 2001). All statistical analyses were conducted using the SPSS software (SPSS 20.0, SPSS Inc, Chicago, USA). Statistical significance level was set at $\alpha=0.05$. All values were expressed as means \pm standard error (S.E.).

\section{Results and discussion}

3.1 Effects of carbon addition or plant species diversity on nitrogen removal efficiency

Low $\mathrm{C}$ availability is one of the factors limiting denitrification process, and then affects $\mathrm{N}$ removal efficiency (Ding et al., 2012). In this study, C addition significantly increased the $\mathrm{N}$ removal efficiency in monocultures, with the average $\mathrm{N}$ removal increased from $56 \%$ to $70 \%$ (Fig. 2a). Our results are similar to previous studies that reported the $\mathrm{N}$ removal efficiency raised to 64\% (Wu et al., 2009) and 62\% (Zhao et al., 2010) with $\mathrm{C}$ addition, respectively. The responses of the four monocultures to $\mathrm{C}$ addition were different: $\mathrm{C}$ addition significantly increased $\mathrm{N}$ removal efficiency in monocultures of $O$. javanica and P. arundinacea (from $42 \%$ to $70 \%$ and from $54 \%$ to 
$67 \%$, respectively), whereas it had no effect on $\mathrm{N}$ removal efficiency in the monocultures of $R$. japonicus and $J$. effusus. In fact, the $\mathrm{N}$ removal efficiency in the monocultures of $R$. japonicus and J. effusus without $\mathrm{C}$ addition $(70 \%$ and $65 \%$, respectively) was similar to those of the monocultures of $O$. javanica and $P$. arundinacea with $\mathrm{C}$ addition (Fig. $2 \mathrm{~d}$, Table 1). These results indicate that there is no need to add C in CWs planted with R. japonicas or J. effusus.

Denitrification and plant $\mathrm{N}$ uptake are two of the main paths of nitrate- $\mathrm{N}$ removal (Vymzal et al., 2007). C addition significantly increased $\mathrm{N}$ removal efficiency in monocultures of $O$. javanica and $P$. arundinacea. As $\mathrm{C}$ addition had no effect on the plant N pool of $O$. javanica and $P$. arundinacea monocultures (Fig. 3c), it is speculated that $\mathrm{C}$ addition enhanced denitrification in the monocultures of these two species. The foliar $\delta^{15} \mathrm{~N}$ of $O$. javanica and $P$. arundinacea monocultures with $\mathrm{C}$ addition were higher than those without $\mathrm{C}$ addition confirming this speculation (Fig. 4a), since the increase in foliar $\delta^{15} \mathrm{~N}$ indicated enhancement of denitrification in the substrate (Vitousek et al., 1989). There was no significant difference in $\mathrm{N}$ removal in the monoculture of $J$. effusus with and without $\mathrm{C}$ addition (Fig. 2b). Although $\mathrm{C}$ addition significantly increased foliar $\delta^{15} \mathrm{~N}$ of $J$. effusus (Fig. 4), the plant $\mathrm{N}$ pool of $J$. effusus in treatments without C addition was higher than that in treatments with $\mathrm{C}$ addition (Fig. 3b). In treatments without $\mathrm{C}$ addition, the foliar ${ }^{15} \mathrm{~N}$ of monocuture of $R$. japonicus was significant higher than that of other three monocultures, indicated high denitrification in sustrate in the monoculture of R. japonicus. C addition had no significant effect on the plant $\mathrm{N}$ pool and foliar $\delta^{15} \mathrm{~N}$ in the monoculture with $R$. japonicus between the treatments with and without $\mathrm{C}$ addition (Fig. 3c and 4a). These results indicate that $\mathrm{C}$ addition does not increase the 
denitrification and $\mathrm{N}$ pool in the monoculture of $R$. japonicus. Overall, the effect of $\mathrm{C}$ addition on $\mathrm{N}$ removal efficiency depends on the species planted in CWs.

Increasing the species richness significantly increased $\mathrm{N}$ removal efficiency from $56 \%$ in monocultures on average to $75 \%$ in the mixture treatments without $\mathrm{C}$ addition (Fig. 2a, Table 1). One of the reasons may be high species richness increased plant $\mathrm{C}$ release. In this study, in the treatments without $\mathrm{C}$ addition, although there was not $\mathrm{C}$ in the supplied simulated wastewater, the $\mathrm{C}$ was test out and the average effluent TOC concentration reached $42 \mathrm{mg} \mathrm{L}^{-1}$, indicating that the plants had released $\mathrm{C}$ into the microcosms. Previous studies reported that higher productive plant can release more $\mathrm{C}$ into the system (Kuzyakov et al., 2001; Cong et al., 2014). The biomass in the four-species mixture was higher than the monoculture on average in both the treatments with and without $\mathrm{C}$ addition (Fig. 5), it is surmised that the mixture produced more $\mathrm{C}$ for denitrification than the monocultures.

Another reason may be that increasing the species richness increases plant $\mathrm{N}$ uptake (Ge et al., 2015). The contribution of plant $\mathrm{N}$ uptake to $\mathrm{N}$ removal ranges from 5-50\% in various types of CWs (Tanner, 2001; Ge et al., 2015). In this study, plant $\mathrm{N}$ uptake significantly increased with increases in species richness (Fig. 3a, Table 2), while the contribution of plant uptake to $\mathrm{N}$ removal averaged $22 \%$ and $42 \%$ in monocultures and four-species mixture without $\mathrm{C}$ addition, respectively (Fig. 3b). Overall, higher species richness increases $\mathrm{N}$ removal efficiency by providing more $\mathrm{C}$ for denitrification and promoting plant $\mathrm{N}$ uptake than monoculture.

In this study, the positive effect on $\mathrm{N}$ removal was stronger by species richness than by $\mathrm{C}$ addition. Compared to the control (monocultures without $\mathrm{C}$ addition), only 
increasing the species richness (four-species mixture) increased the $\mathrm{N}$ removal by $34 \%$ on average, and only adding $\mathrm{C}$ increased the $\mathrm{N}$ removal by $25 \%$ on average (Fig. 2a). $\mathrm{C}$ addition only enhanced denitrification, while increasing the species richness not only enhanced denitrification but also promoted the plant $\mathrm{N}$ pool. Compared to the control, four-species mixture with $\mathrm{C}$ addition also increased $\mathrm{N}$ removal, but there was no significant difference between four-species mixture with $\mathrm{C}$ addition and without $\mathrm{C}$ addition (Fig. 2a). Assembling community with high species richness as a low-cost approach for increasing $\mathrm{N}$ removal efficiency can replace $\mathrm{C}$ addition in $\mathrm{CWs}$ in some extent.

\subsection{Effects of carbon addition or plant species diversity on $\mathrm{N}_{2} \mathrm{O}$ emissions}

The proportion of loaded $\mathrm{N}$ emitted as $\mathrm{N}_{2} \mathrm{O}-\mathrm{N}$ can range from $0.001-3.010 \%$ in CWs for wastewater treatment (Mander et al., 2014). In this study, the proportion was $0.001-0.250 \%$. The $\mathrm{C}$ availability in wastewater may affect aerobic and anaerobic conditions in CWs and consequently may influence $\mathrm{N}_{2} \mathrm{O}$ emissions from treating wastewater (Kampschreur et al., 2009; Huang et al., 2013). In this study, C addition significantly increased $\mathrm{N}_{2} \mathrm{O}$ emissions rate in monocultures, with the average $\mathrm{N}_{2} \mathrm{O}$ emissions rate increased from 0.38 to $1.26 \mathrm{mg} \mathrm{m}^{-2} \mathrm{~d}^{-1}$ (Fig. 2b). Previous studies have shown that the $\mathrm{N}_{2} \mathrm{O}$ emission rate from Phragmites australis monoculture is at a minimum $\left(3.68 \mathrm{mg} \mathrm{m}^{-2} \mathrm{~d}^{-1}\right)$ when the $\mathrm{C} / \mathrm{N}$ ratio $=5(\mathrm{Wu}$ et al., 2009). Although the amount of $\mathrm{C}$ addition was relatively low $(\mathrm{C} / \mathrm{N}=1)$ in this study, the $\mathrm{N}_{2} \mathrm{O}$ emission rates were still lower than the $\mathrm{N}_{2} \mathrm{O}$ emission rate under optimal $\mathrm{C} / \mathrm{N}$ in available literature (e.g., Wu et al., 2009). The responses of the four species monocultures to $\mathrm{C}$ 
addition were different. In the monoculture of $J$. effusus, C addition significantly increased $\mathrm{N}_{2} \mathrm{O}$ emission rates from 0.41 to $2.28 \mathrm{mg} \mathrm{m}^{-2} \mathrm{~d}^{-1}$, but this addition had no significant effect on other three species (Fig. 2e).

Increasing species richness significantly increased $\mathrm{N}_{2} \mathrm{O}$ emission rates from 0.41 $\mathrm{mg} \mathrm{m} \mathrm{m}^{-2}$ in monocultures to $1.4 \mathrm{mg} \mathrm{m}^{-2} \mathrm{~d}^{-1}$ in four-species mixture without $\mathrm{C}$ addition (Fig. 2b, Table 1). This result was consistent with that of Sun et al. (2013) and Chang et al. (2014), which reported that higher species richness increased $\mathrm{N}_{2} \mathrm{O}$ emission rate in $\mathrm{CW}$ microcosms. One of the reasons may be that higher species richness produced more $\mathrm{C}$ (as discussed above) and then enhanced denitrification and increased the $\mathrm{N}_{2} \mathrm{O}$ emission rate. Another reason may be increasing the species richness increased the capability of transferring $\mathrm{N}_{2} \mathrm{O}$ from roots up to the atmosphere (Jørgensen et al., 2012).

Comparing the effects of $\mathrm{C}$ addition and species richness on $\mathrm{N}_{2} \mathrm{O}$ emission rate, $\mathrm{C}$ addition increased $\mathrm{N}_{2} \mathrm{O}$ emission rate by $231 \%$ on average, while the species richness increased $\mathrm{N}_{2} \mathrm{O}$ emission rate by $269 \%$ on average compared to control; also, there was no significant difference between the treatments of $\mathrm{C}$ addition and increasing species richness (Fig. 2b). The results indicate that the positive effect of species richness on $\mathrm{N}_{2} \mathrm{O}$ emission rate is equal to the positive effect of $\mathrm{C}$ addition.

The responses of the $\mathrm{N}_{2} \mathrm{O}-\mathrm{N}$ emissions per unit $\mathrm{N}$ removal in the four monocultures to $\mathrm{C}$ addition varied in our study. $\mathrm{C}$ addition significantly increased the $\mathrm{N}_{2} \mathrm{O}-\mathrm{N}$ emissions per unit $\mathrm{N}$ removal in $P$. arundinacea and $J$. effusus monocultures, but other two species monocultures had no significant response to $\mathrm{C}$ addition (Fig. 2f). Compared to the control, the mixture without $\mathrm{C}$ addition and the mixture with $\mathrm{C}$ addition both had 
no significant effect on $\mathrm{N}_{2} \mathrm{O}-\mathrm{N}$ emissions per unit $\mathrm{N}$ removal (Fig. 2c, Table 1). In sum, assembling communities with high species richness can improve $\mathrm{N}$ removal and does not increase the $\mathrm{N}_{2} \mathrm{O}-\mathrm{N}$ emissions per unit $\mathrm{N}$ removal.

3.3 Relative importance of the effects of species richness and species identity

Most previous experiments in grassland and marine communities have shown that species identity played a more important role than species richness in controlling ecosystem processes (e.g., Hooper and Vitousek, 1998; Bruno et al., 2005). In this study, species richness had a stronger influence on aboveground biomass than species identity in treatments with or without $\mathrm{C}$ addition. In this case, species richness explained more than $50 \%$ of the variation, whereas species identity only accounted for about $30 \%$ of the variation (Table 2). However, species identity influenced below-ground biomass more strongly than species richness. Species identity explained more than $70 \%$ of the variation, whereas species richness only explained less than $20 \%$ of the variation (Table 2). Species identity had no effect on $\mathrm{N}$ removal in treatments with and without $\mathrm{C}$ addition (Table 1), although species identity significantly affected the plant $\mathrm{N}$ pool (Table 2), which was one of the main pathways for $\mathrm{NO}_{3}{ }^{-} \mathrm{N}$ removal. The difference in the plant $\mathrm{N}$ pool may be offset by the difference in denitrification, which was the other main pathway for $\mathrm{NO}_{3}{ }^{-} \mathrm{N}$ removal (Vymzal et al., 2007). However, species richness significantly affected $\mathrm{N}$ removal, explaining $31 \%$ of the variation in $\mathrm{N}$ removal in treatments without $\mathrm{C}$ addition (Table 1). The results demonstrate that species richness influence the $\mathrm{N}$ removal more strongly than species identity.

Species identity surpassing species richness as a key driver of $\mathrm{N}_{2} \mathrm{O}$ emissions in 
grassland has been reported by Abalos et al. (2014). In this study, species richness significantly affected $\mathrm{N}_{2} \mathrm{O}$ emissions from $\mathrm{CWs}$ where there was no $\mathrm{C}$ addition, whereas species identity had no effect. Species richness and species identity both had no significant effect on $\mathrm{N}_{2} \mathrm{O}$ emissions from CWs with $\mathrm{C}$ addition (Table 1). In treatments without $\mathrm{C}$ addition, the available $\mathrm{C}$ amount may be the main factor affecting $\mathrm{N}_{2} \mathrm{O}$ emissions, and species richness was determined to be the key driver of $\mathrm{N}_{2} \mathrm{O}$ emissions by producing more $\mathrm{C}$. However, in treatments with $\mathrm{C}$ addition, the $\mathrm{N}_{2} \mathrm{O}$ emissions may be affected by other relevant factors, such as $\mathrm{N}$ concentration. Overall, our results suggest that the effects of species richness on the $\mathrm{N}$ removal and $\mathrm{N}_{2} \mathrm{O}$ emissions are both stronger than the effects of species identity.

\section{Conclusions}

Overall, this study showed that higher species richness and $\mathrm{C}$ addition both increased $\mathrm{N}$ removal efficiency and $\mathrm{N}_{2} \mathrm{O}$ emission rate, but had no effect on the $\mathrm{N}_{2} \mathrm{O}-\mathrm{N}$ emission per unit $\mathrm{N}$ removal. The effects of species richness on $\mathrm{N}$ removal efficiency and $\mathrm{N}_{2} \mathrm{O}$ emission were greater than species identity. Assembling communities with high species richness as an alternative approach to $\mathrm{C}$ addition could be an effective and more economical approach to improving the $\mathrm{N}$ removal efficiency and would not increase $\mathrm{N}_{2} \mathrm{O}-\mathrm{N}$ emission per unit $\mathrm{N}$ removal in $\mathrm{CWs}$ for treating low $\mathrm{C} / \mathrm{N}$ ratio wastewater.

\section{Acknowledgements}

This work was funded by the National Science Foundation of China (No. 31270377, 31170305 and 51279121). 


\section{References}

Abalos, D., Deyn, G. B., Kuyper, T. W., Groenigen, J. W., 2014. Plant species identity surpasses species richness as a key driver of $\mathrm{N}_{2} \mathrm{O}$ emissions from grassland. Global Change Biol. 20, 265-275.

Bruno, J. F., Boyer, K. E., Duffy, J. E., Lee, S. C., Kertesz, J. S., 2005. Effects of macroalgal species identity and richness on primary production in benthic marine communities. Ecol. Lett. 8, 1165-1174.

Canfield, D. E., Glazer, A. N., Falkowski, P. G., 2010. The evolution and future of Earth's nitrogen cycle. Science. 330, 192-196.

Chang, J., Fan, X., Sun, H. Y., Zhang, C. B., Song, C. C., Chang, S. X., Gu B. J., Liu L., Li, L., Wang, Y., Ge, Y., 2014. Plant species richness enhances nitrous oxide emissions in microcosms of constructed wetlands. Ecol. Eng. 64, 108-115.

Cheng, X.L., Peng, R.H., Chen, J.Q, Luo, Y.Q., Zhang, Q.F., An, S.Q., Chen, J.K., Li, B., 2007. $\mathrm{CH}_{4}$ and $\mathrm{N}_{2} \mathrm{O}$ emissions from Spartina alterniflora and Phragmites australis in experimental mesocosms. Chemosphere. 68, 420-427.

Clescerl, LS, Greenberg AE., Eaton AD. (Eds), 1999. Standard Method for the Examination of Water and Wastewater. Washington: American Public Health Association, American Water Works Association, Water Environment Federation.

Cong, W. F., Ruijven, J., Mommer, L., De Deyn, G. B., Berendse, F., Hoffland, E., 2014. Plant species richness promotes soil carbon and nitrogen stocks in grasslands without legumes. J. Ecol. 102, 1163-1170.

De Deyn, G. B., Cornelissen, J. H., Bardgett, R. D., 2008. Plant functional traits and soil carbon sequestration in contrasting biomes. Ecol. Lett. 11, 516-531. 
Ding, Y., Song, X.S., Wang, Y.H., Yan, D.H., 2012. Effects of dissolved oxygen and influent $\mathrm{COD} / \mathrm{N}$ ratios on nitrogen removal in horizontal subsurface flow constructed wetland. Ecol. Eng. 46, 107-111.

Galloway, J. N., Townsend, A. R., Erisman, J. W., Bekunda, M., Cai, Z. C., Freney, J. R., Martinelli, L. A., Seitzinger, S. P., Sutton, M. A., 2008. Transformation of the nitrogen cycle: recent trends, questions, and potential solutions. Science. 320, 889-892.

Ge, Y., Han, W.J., Huang, C.C., Wang, H., Liu, D., Chang, S. X., Gu, B.H., Zhang, C.B., Gu, B.J., Fan, X., Du, Y.Y., Chang, J., 2015. Positive effects of plant diversity on nitrogen removal in microcosms of constructed wetlands with high ammonium loading. Ecol. Eng. 82, 614-623.

Graham, M.H., Edwards, M.S., 2001. Statistical significance versus fit: estimating the importance of individual factors in ecological analysis of variance. Oikos. 93, $505-513$

Hoagland, D.R., Arnon, D.J. 1950. The water culture method for growing plants without soil. Calif. Agric. 347, 1-32.

Hooper, D. U., Vitousek, P. M., 1998. Effects of plant composition and diversity on nutrient cycling. Ecol. Monogra. 68, 121-149.

Huang, L., Gao, X., Guo, J., Ma, X., Liu, M., 2013. A review on the mechanism and affecting factors of nitrous oxide emission in constructed wetlands. Environ. Earth Sci. 68, 2171-2180.

Jørgensen, C. J., Struwe, S., Elberling, B., 2012. Temporal trends in $\mathrm{N}_{2} \mathrm{O}$ flux dynamics in a Danish wetland - effects of plant - mediated gas transport of $\mathrm{N}_{2} \mathrm{O}$ and $\mathrm{O}_{2}$ 
following changes in water level and soil mineral - $\mathrm{N}$ availability. Global Change Biol. 18, 210-222.

Kampschreur, M. J., Temmink, H., Kleerebezem, R., Jetten, M. S., van Loosdrecht, M. C., 2009. Nitrous oxide emission during wastewater treatment. Water Res. 43, 4093-4103.

Kumar, M., Lee, P.Y., Fukusihma, T., Whang, L.M., Lin, J.G., 2012. Effect of supplementary carbon addition in the treatment of low $\mathrm{C} / \mathrm{N}$ high-technology industrial wastewater by MBR. Bioresource Technol. 113, 148-153.

Kuzyakov, Y., Ehrensberger, H., Stahr, K., 2001. Carbon partitioning and below-ground translocation by Lolium perenne. Soil Biol. Biochem. 33, 61-74.

Lange, M., Eisenhauer, N., Sierra, C. A., Bessler, H., Engels, C., Griffiths, R. I., Gleixner, G., 2015. Plant diversity increases soil microbial activity and soil carbon storage. Nat. Commun. 6, 1-7.

Liu, D., Wu, X., Chang, J., Gu, B.J., Min, Y., Ge, Y., Shi, Y., Xue, H., Peng, C.H., Wu, J.G., 2012. Constructed wetlands as biofuel production systems. Nat. Commun. 2, 190-194.

Mander, Ü., Dotro, G., Ebie, Y., Towprayoon, S., Chiemchaisri, C., Nogueira, S. F., Jamsranjav, S., Kasak, K., Truu, J., Tournebize, J., Mitsch, W.J., 2014. Greenhouse gas emission in constructed wetlands for wastewater treatment: a review. Ecol. Eng. $66,19-35$.

Niklaus, P. A., Wardle, D. A., Tate, K. R., 2006. Effects of plant species diversity and composition on nitrogen cycling and the trace gas balance of soils. Plant Soil. 282, 83-98. 
Picek, T., Č́ížková, H., Dušek, J., 2007.Greenhouse gas emissions from a constructed wetland-plants as important sources of carbon. Ecol. Eng. 31 98-106.

Read, J., Wevill, T., Fletcher, T., Deletic, A., 2008. Variation among plant species in pollutant removal from stormwater in biofiltration systems. Water Res. 42, 893-902.

Saeed, T., Sun, G., 2011. Enhanced denitrification and organics removal in hybrid wetland columns: comparative experiments. Bioresour. Technol. 102, 967-974.

Schwarzenbach, R. P., Egli, T., Hofstetter, T. B., Von Gunten, U., Wehrli, B., 2010. Global water pollution and human health. Annu. Rev.Env.Resour. 35, 109-136.

Sirivedhin, T., Gray, K. A., 2006. Factors affecting denitrification rates in experimental wetlands: field and laboratory studies. Ecol. Eng. 26, 167-181.

Sun, H. Y., Zhang, C. B., Song, C.C., Chang, S. X., Gu, B.J., Chen, Z.X., Peng, C.H., Chang, J., Ge, Y., 2013. The effects of plant diversity on nitrous oxide emissions in hydroponic microcosms. Atmos. Environ. 77, 544-547.

Tanner, C. C., 2001. Growth and nutrient dynamics of soft-stem bulrush in constructed wetlands treating nutrient-rich wastewaters. Wetl. Ecol.Manag. 9, 49-73.

Thomson, A. J., Giannopoulos, G., Pretty, J., Baggs, E. M., Richardson, D. J., 2012. Biological sources and sinks of nitrous oxide and strategies to mitigate emissions. Philos. T. R. Soc. B. 367, 1157-1168.

Tilman, D., Reich, P. B., Isbell, F. 2012. Biodiversity impacts ecosystem productivity as much as resources, disturbance, or herbivory. P. Natl. Acad. Sci. Usa. 109, 10394-10397.

Vitousek, P. M., Shearer, G., Kohl, D. H., 1989. Foliar ${ }^{15} \mathrm{~N}$ natural abundance in 
Hawaiian rainforest: patterns and possible mechanisms. Oecologia. 78, 383-388.

Vymazal, J., 2007. Removal of nutrients in various types of constructed wetlands. Sci. Total Environ. 380, 48-65.

Vymazal, J., 2014. Constructed wetlands for treatment of industrial wastewaters: A review. Ecol. Eng. 73, 724-751.

Wu, J., Zhang, J., Jia, W.L., Xie, H.J., Gu, R. R., Li, C., Gao, B. Y., 2009. Impact of $\mathrm{COD} / \mathrm{N}$ ratio on nitrous oxide emission from microcosm wetlands and their performance in removing nitrogen from wastewater. Bioresour. Technol. 100, 2910-2917.

Wu, S., Kuschk, P., Brix, H., Vymazal, J., Dong, R., 2014. Development of constructed wetlands in performance intensifications for wastewater treatment: a nitrogen and organic matter targeted review. Water Res. 57, 40-55.

Zhao, Y. J., Liu, B., Zhang, W. G., Ouyang, Y., An, S. Q., 2010. Performance of pilot-scale vertical-flow constructed wetlands in responding to variation in influent $\mathrm{C} / \mathrm{N}$ ratios of simulated urban sewage. Bioresour. Technol. 101, 1693-1700. 


\section{Figure captions}

Fig. 1 Experimental design. White background: treatments without carbon addition; grey background: treatments with carbon addition. Different shapes represent different species.

Fig. 2 Effects of $\mathrm{C}$ addition and plant species diversity on (a, d) nitrogen removal efficiency, (b, e) $\mathrm{N}_{2} \mathrm{O}$ emission rate and (c, f) $\mathrm{N}_{2} \mathrm{O}-\mathrm{N}$ emission per unit $\mathrm{N}$ removal. White background: treatments without carbon addition; grey background: treatments with carbon addition. Rj: R. japonicuas; Oj: O. javanica; Pa: P. arundinacea; Je: J. effuses. Different letters denote significant difference among treatments. Asterisks denote significant difference between treatments with carbon addition and without carbon addition $(P<0.05)$. There was no significant difference among four monocultures in both treatments with and without carbon addition. Mean \pm S.E. Results on species richness and identity effects are in Table 1.

Fig. 3 Effects of $\mathrm{C}$ addition and plant species diversity on $(\mathrm{a}, \mathrm{c})$ total plant $\mathrm{N}$ pool and (b, d) the contribution of plant $\mathrm{N}$ uptake on TIN removal. Background and species abbreviations are the same as in Fig.2. Different letters denote significant difference among treatments. There was no significant difference between the treatments without carbon addition and with carbon addition. Mean \pm S.E. Results on species richness and identity effects are in Table 2. 
Fig. 4 Foliar $\delta^{15} \mathrm{~N}$ in monocultures. Background and species abbreviations are the same as in Fig.2. Asterisks denote significant difference between treatments with and without carbon addition $(P<0.05)$. Mean \pm S.E.

Fig. 5 Effects of $\mathrm{C}$ addition and plant species diversity on (a, c) aboveground biomass and $(b, d)$ belowground biomass. Background and species abbreviations are the same in Fig.2. Different letters denote significant difference among treatments. There was no significant difference between the treatments with and without carbon addition. Mean \pm S.E. Results on species richness and identity effects are in Table 2. 


\section{FIGURES}

Fig. 1

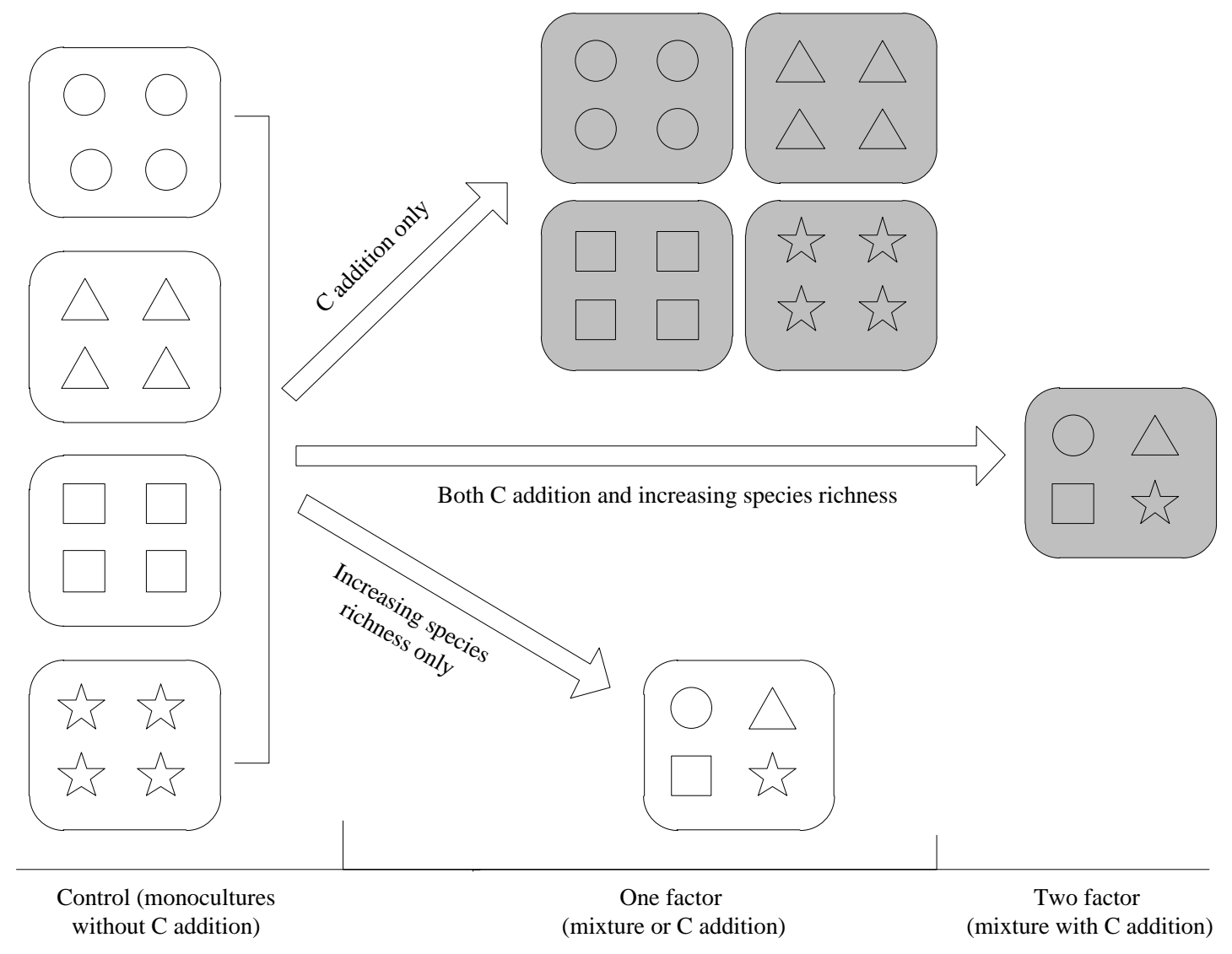


Fig. 2
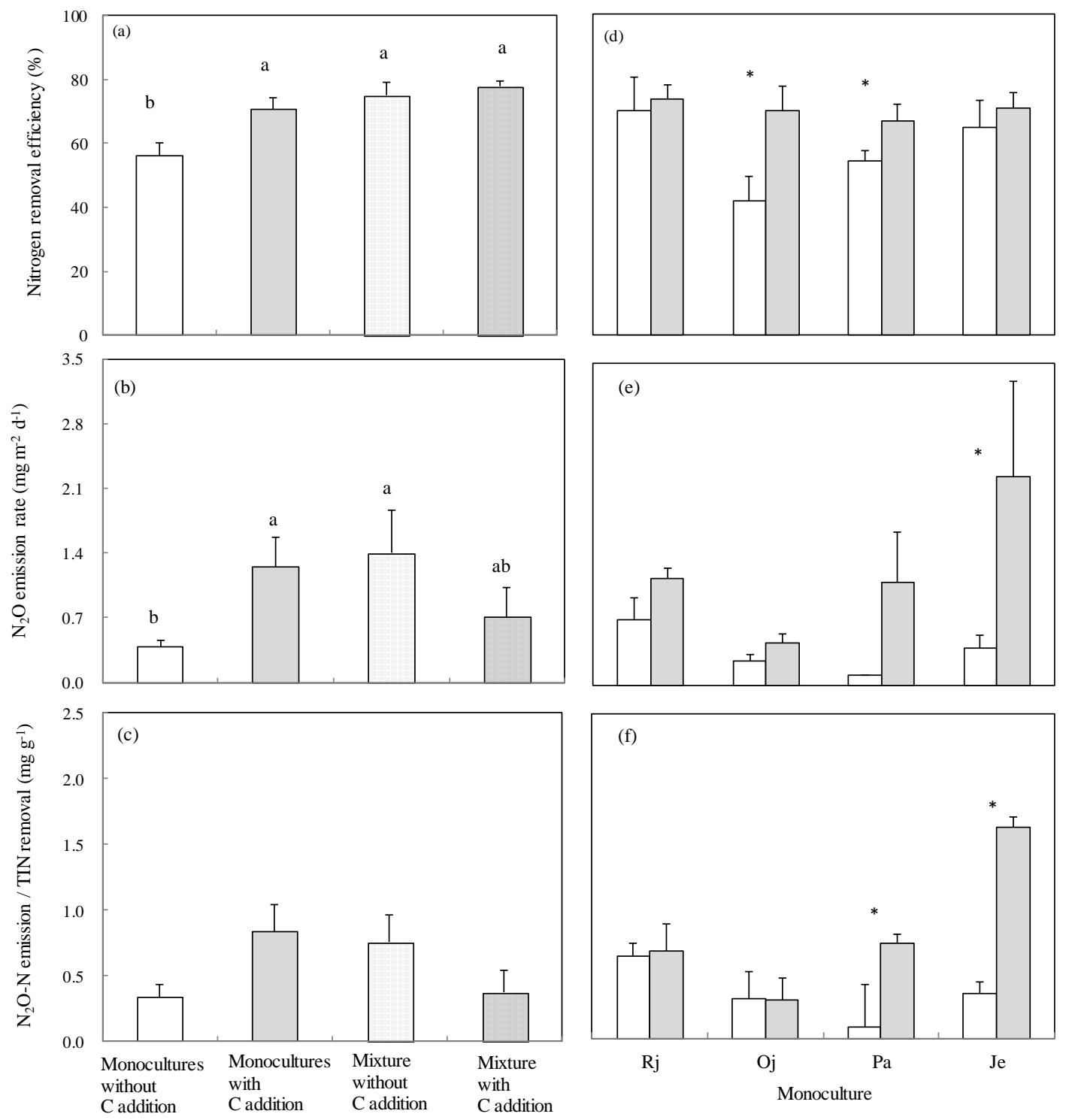
Fig.3
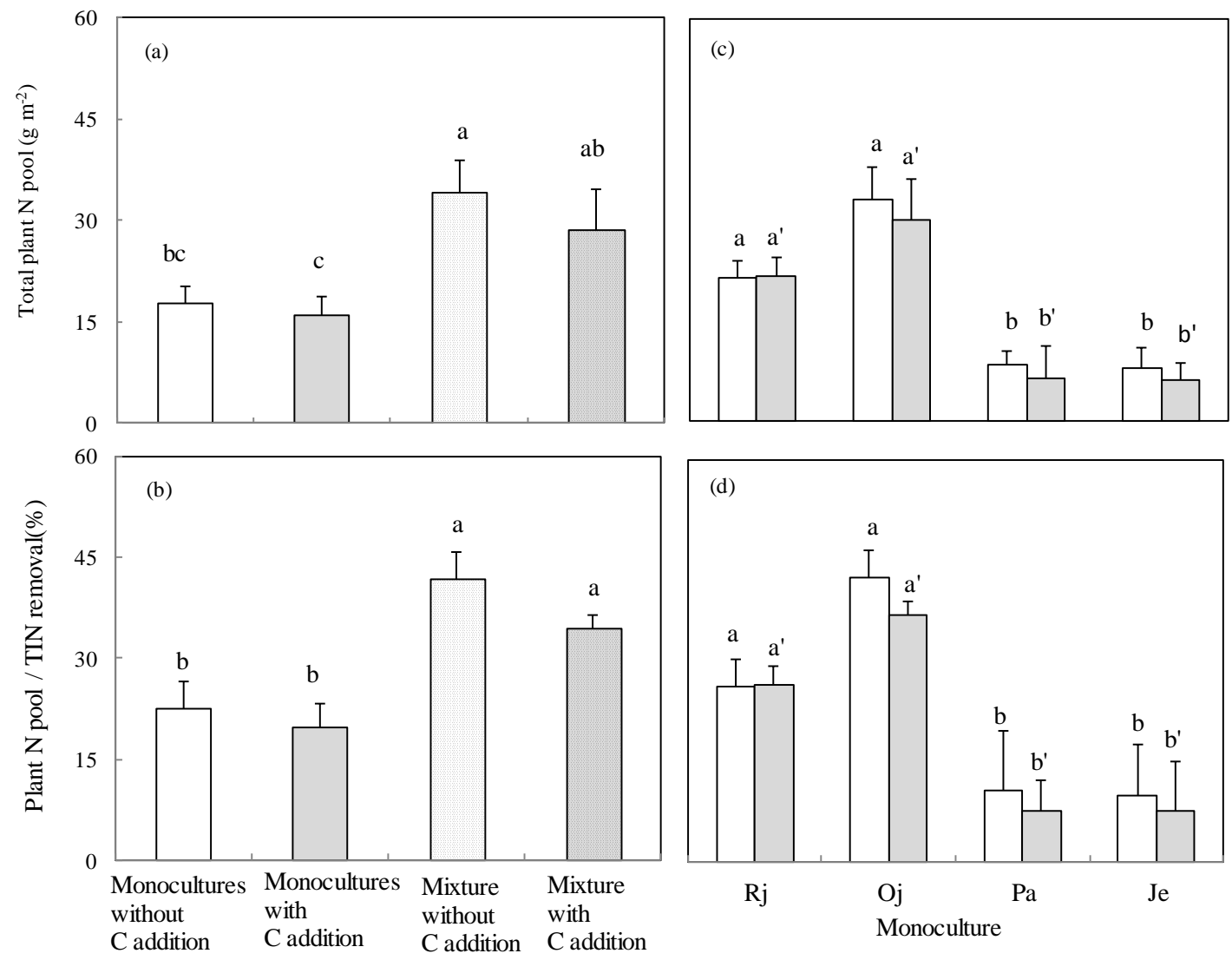
Fig. 4

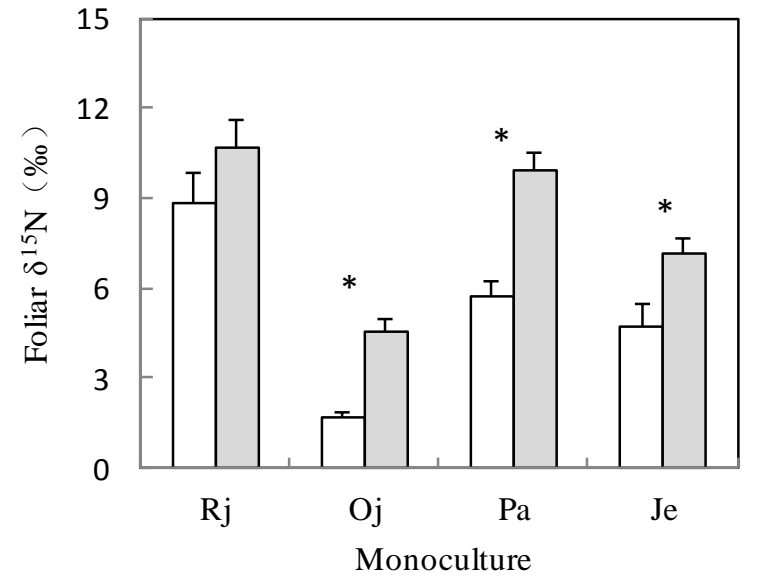


Fig. 5
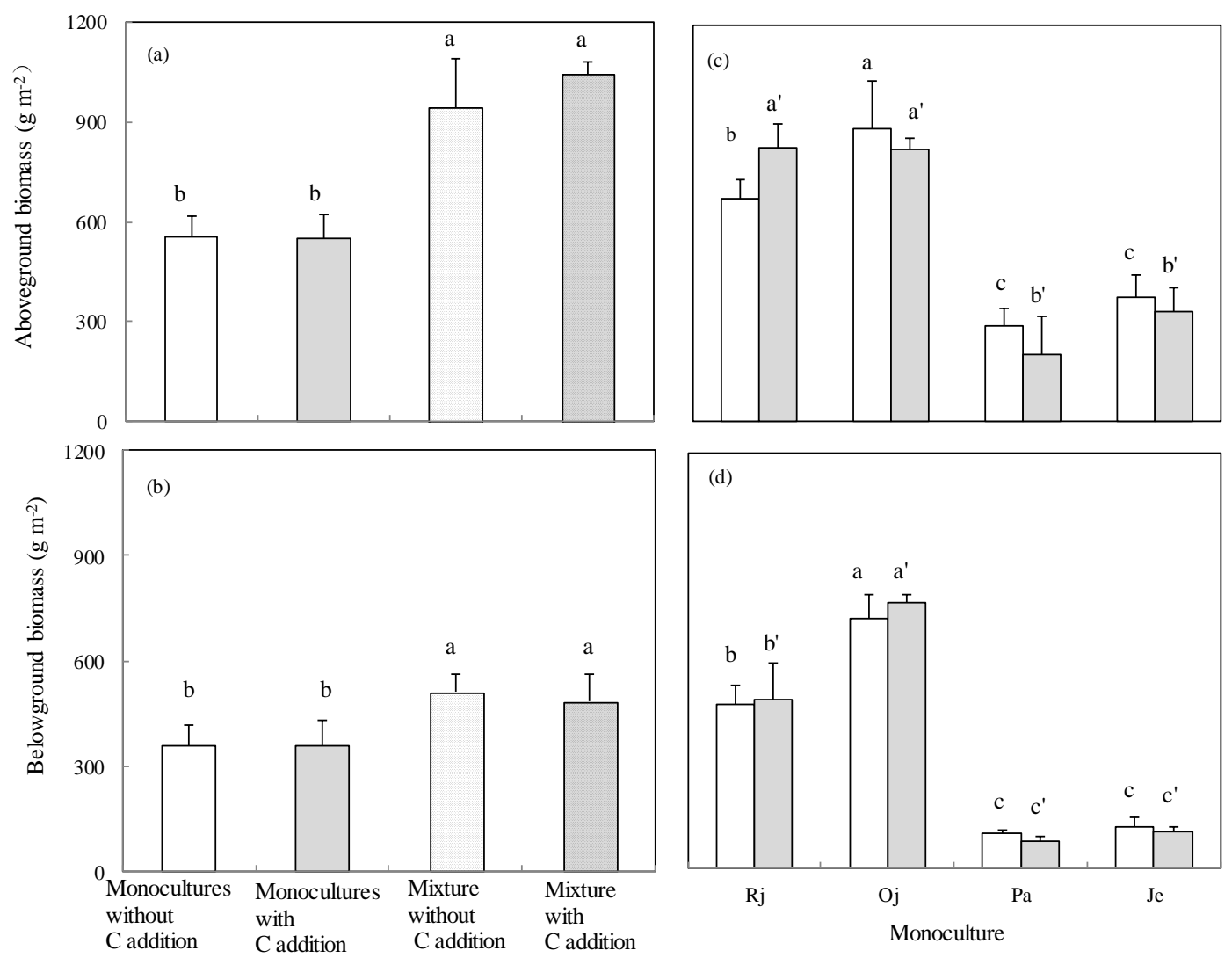
Table 1 Analysis of variance (ANOVA) data on the effects of plant species richness and identity on $\mathrm{N}$ removal efficiency (\%), $\mathrm{N}_{2} \mathrm{O}$ emission rate $\left(\mathrm{mg} \mathrm{m}^{-2} \mathrm{~d}^{-1}\right)$ and $\mathrm{N}_{2} \mathrm{O}-\mathrm{N}$ emission /TIN removal $\left(\mathrm{mg} \mathrm{g}^{-1}\right)$.

\begin{tabular}{|c|c|c|c|c|c|c|c|}
\hline Variables & Treatments & $\begin{array}{l}\text { Sources } \\
\text { of effect }\end{array}$ & SS & d.f. & $\mathrm{F}$ & $\mathrm{P}$ & $\omega^{2}$ \\
\hline $\mathrm{N}$ & without $\mathrm{C}$ addition & Richness & 1208.07 & 1 & 4.56 & 0.045 & 30.25 \\
\hline removal & & Identity & 2355.97 & 3 & 2.97 & 0.057 & 16.69 \\
\hline \multirow[t]{2}{*}{ efficiency } & with $\mathrm{C}$ addition & Richness & 400.01 & 1 & 1.63 & 0.216 & 9.10 \\
\hline & & Identity & 325.17 & 3 & 0.44 & 0.727 & 0.00 \\
\hline $\mathrm{N}_{2} \mathrm{O}$ & without $\mathrm{C}$ addition & Richness & 4.19 & 1 & 14.79 & 0.001 & 68.16 \\
\hline emission & & Identity & 1.01 & 3 & 1.19 & 0.339 & 0.94 \\
\hline \multirow[t]{2}{*}{ rate } & with $\mathrm{C}$ addition & Richness & 1.20 & 1 & 0.82 & 0.377 & 0.00 \\
\hline & & Identity & 8.49 & 3 & 1.92 & 0.159 & 13.22 \\
\hline $\mathrm{N}_{2} \mathrm{O}-\mathrm{N}$ & without $\mathrm{C}$ addition & Richness & 0.70 & 1 & 3.62 & 0.072 & 29.10 \\
\hline emission & & Identity & 0.66 & 3 & 1.15 & 0.353 & 1.64 \\
\hline$/ \mathrm{TIN}$ & with $\mathrm{C}$ addition & Richness & 1.29 & 1 & 2.12 & 0.161 & 10.54 \\
\hline removal & & Identity & 4.74 & 3 & 2.60 & 0.079 & 30.84 \\
\hline
\end{tabular}

Richness and identity effects were tested with orthogonal planned contrasts. Effect sizes were estimated as $\omega^{2}$ (Graham and Edwards, 2001), with negative estimates reported as zero. Significant $P$ values $(P<0.05)$ are highlighted. 
Table 2 Analysis of variance (ANOVA) data on the effects of plant species richness and identity on biomass $\left(\mathrm{g} \mathrm{m}^{-2}\right)$, plant $\mathrm{N}$ pool $\left(\mathrm{g} \mathrm{m}^{-2}\right)$ and plant $\mathrm{N}$ pool /TIN removal $(\%)$.

\begin{tabular}{|c|c|c|c|c|c|c|c|}
\hline Variables & Treatments & $\begin{array}{l}\text { Sources } \\
\text { of effect }\end{array}$ & SS & d.f. & $\mathrm{F}$ & $\mathrm{P}$ & $\omega^{2}$ \\
\hline \multirow{4}{*}{$\begin{array}{l}\text { Aboveground } \\
\text { biomass }\end{array}$} & without & Richness & 593719.47 & 1 & 17.78 & $<0.001$ & 50.46 \\
\hline & $\mathrm{C}$ addition & Identity & 1124218.91 & 3 & 11.22 & $<0.001$ & 30.74 \\
\hline & with & Richness & 987137.27 & 1 & 46.80 & $<0.001$ & 60.07 \\
\hline & $\mathrm{C}$ addition & Identity & 1594181.54 & 3 & 25.19 & $<0.001$ & 31.73 \\
\hline \multirow{4}{*}{$\begin{array}{l}\text { Belowground } \\
\text { biomass }\end{array}$} & without & Richness & 96648.55 & 1 & 8.80 & 0.008 & 14.6 \\
\hline & $\mathrm{C}$ addition & Identity & 1329607.57 & 3 & 40.33 & $<0.001$ & 73.69 \\
\hline & with & Richness & 63465.16 & 1 & 3.465 & 0.077 & 6.57 \\
\hline & $\mathrm{C}$ addition & Identity & 1638154.61 & 3 & 29.82 & $<0.001$ & 76.78 \\
\hline \multirow[t]{4}{*}{ Plant N pool } & without & Richness & 1068.455 & 1 & 27.59 & $<0.001$ & 52.83 \\
\hline & $\mathrm{C}$ addition & Identity & 2148.456 & 3 & 18.50 & $<0.001$ & 34.75 \\
\hline & with & Richness & 626.061 & 1 & 9.24 & 0.006 & 34.66 \\
\hline & $\mathrm{C}$ addition & Identity & 2090.899 & 3 & 10.29 & $<0.001$ & 39.06 \\
\hline \multirow{4}{*}{$\begin{array}{l}\text { Plant N pool/ } \\
\text { TIN removal }\end{array}$} & without & Richness & 0.149 & 1 & 24.83 & $<0.001$ & 48.72 \\
\hline & $\mathrm{C}$ addition & Identity & 0.357 & 3 & 19.83 & $<0.001$ & 38.50 \\
\hline & with & Richness & 0.087 & 1 & 8.70 & 0.008 & 32.79 \\
\hline & $\mathrm{C}$ addition & Identity & 0.316 & 3 & 10.53 & 0.001 & 40.60 \\
\hline
\end{tabular}

Richness and identity effects were tested with orthogonal planned contrasts. Effect sizes were estimated as $\omega^{2}$ (Graham and Edwards, 2001). Significant $\mathrm{P}$ values $(P<$ 0.05) are highlighted. 